\title{
Research of Vacuum Honey Drying Processes
}

\author{
Ermolaev V.A.* \\ Department of Commodity Science and Expertise \\ Plekhanov Russian University of Economics \\ Moscow, Russia \\ e-mail: ermolaevvla@rambler.ru \\ Kechkin I.A. \\ Department of Commodity Science and Expertise \\ Plekhanov Russian University of Economics \\ Moscow, Russia
}

\author{
Romanenko A.I. \\ K.G. Razumovsky Moscow State University of technologies \\ and management (the First Cossack University) \\ Moscow, Russia
}

Tarakanova V.V.

K.G. Razumovsky Moscow State University of technologies and management (the First Cossack University)

Moscow, Russia

\author{
Glebova I.A. \\ K.G. Razumovsky Moscow State University of technologies and management \\ (the First Cossack University) \\ Moscow, Russia
}

\begin{abstract}
The article is devoted to the effective mode selection for vacuum honey drying. There were studied an impact of the drying layer thickness and heat flux density on the efficiency of vacuum honey dehydration. Experiments on vacuum drying of honey were carried out at a heat flux density from 2 to $10 \mathrm{~kW} / \mathrm{m}^{2}$. The dependences of the relative product mass on the vacuum drying process duration were obtained. If a heat flux density increases, the drying time reduces: when a heat flux density was 2,4 and $6 \mathrm{~kW} / \mathrm{m}^{2}$, the drying time lasted for $270 \pm 10$, $240 \pm 10$ and $225 \pm 10 \mathrm{~min}$ respectively; while at a heat flux density of 8 and $10 \mathrm{~kW} / \mathrm{m}^{2}$, the time was $210 \pm 10$ and $195 \pm 10 \mathrm{~min}$, respectively. At the same time, the moisture content of the dehydrated product also changes: an increase in the heat flux density from 2 to $10 \mathrm{~kW} / \mathrm{m}^{2}$ leads to the moisture content changes from 4.5 to $5 \%$. Experimental studies were carried out on vacuum honey drying at a product layer thickness of 5 to $20 \mathrm{~mm}$. It was established that an increase in the layer thickness entails an increase in the drying time, an increase in the moisture content of the dehydrated product, and a decrease in its quality. However, this increases the productivity of the drying unit. Based on the studies, the following effective modes of vacuum honey drying were determined - heat flux density $-4 \mathrm{~kW} / \mathrm{m}^{2}$, product layer thickness $-15 \mathrm{~mm}$. It is advisable to dehydrate honey at a residual pressure of $4 \pm 0.5 \mathrm{kPa}$ and at a temperature of $40{ }^{\circ} \mathrm{C}$ in the drying chamber. Under these conditions, the drying time is $275 \pm 10$ minutes, and the organoleptic evaluation of the dry product is 34 points out of 40 .
\end{abstract}

Keywords - vacuum honey dehydration, mode selection, vacuum drying process.

\section{INTRODUCTION}

Bee honey is a biologically active product, the advantage of which is not only high energy value (on average it is about $300-340 \mathrm{kcal}$ per $100 \mathrm{~g}$ ), but also it obtains a large number of valuable minerals, enzymes, vitamins, organic acids, aromatic and antimicrobial substances causing its healing properties $[1,2]$.
One of the advantages of this product is the fact of its $100 \%$ absorption by the body, unlike most other sweet foods. Ripe honey contains not more than $21 \%$ water, about $35 \%$ glucose, $40 \%$ fructose, $1.3 \%$ sucrose, $0.45 \%$ protein, $0.1 \%$ organic acids and $0.2 \%$ minerals [3].

Honey always contains pollen, which enters nectar during the movement of a bee and additionally enriches the product with vitamins, minerals and proteins. Honey contains all B vitamins, as well as vitamins $\mathrm{A}, \mathrm{H}$, nicotinic acid and biotin. About 40 micro and macro elements were found in this product, including potassium, calcium, cobalt, iron, phosphorus, honey, magnesium, manganese, aluminum, iodine, zinc, etc. Moreover, the concentration and ratio of some micro elements in honey corresponds to those in human blood, which defines its rapid assimilation [4-6].

For technological reasons, or to avoid biochemical changes that occur in honey due to the presence of a certain amount of moisture, there is a need for dehydration of this product.

The traditional method of honey dehydration is a convective method, which involves direct contact of the product with heated air. It is not recommended to exceed a temperature of $40{ }^{\circ} \mathrm{C}$ to preserve biologically useful components.

An alternative method of drying is vacuum dehydration. As a result of lowering the pressure, the boiling point decreases and the rate of moisture removal increases [7].

\section{PURPOSE AND OBJECTIVES OF RESEARCH}

The purpose of this research was to study the processes of vacuum honey drying under various conditions.

Within the aim framework, the following objectives were set: 
- kinetics analysis of the process of vacuum honey drying;

- study of the influence of technological parameters on the efficiency of vacuum honey drying process;

- selection of effective modes of vacuum dehydration of honey.

\section{METHODS AND OBJECTS OF RESEARCH}

The object of the carried research was natural buckwheat honey produced by Bashkir Honey Company. Organoleptic characteristics of the studied object are shown in Table 1.

TABLE I. ORGANOLEPTIC CHARACTERISTICS OF HONEY

\begin{tabular}{|l|l|}
\hline \multicolumn{1}{|c|}{ Indicator } & \multicolumn{1}{c|}{ Characteristics } \\
\hline Taste & Sweet, pleasant, lack of extraneous tastes \\
\hline Color & Light Amber \\
\hline Odor & Particular, odorless \\
\hline Consistency & Syrupy consistency \\
\hline
\end{tabular}

To carry out these experimental studies, a vacuum drying unit was used, the scheme of which is shown in Figure 1.

All the experiments were conducted in the vacuum chamber at the following conditions: temperature $-40 \pm 2{ }^{\circ} \mathrm{C}$, residual pressure $-4 \pm 0.5 \mathrm{kPa}$. Every experiment was carried out in triplicate to obtain more reliable results. Data was processed in Microsoft Excel software.

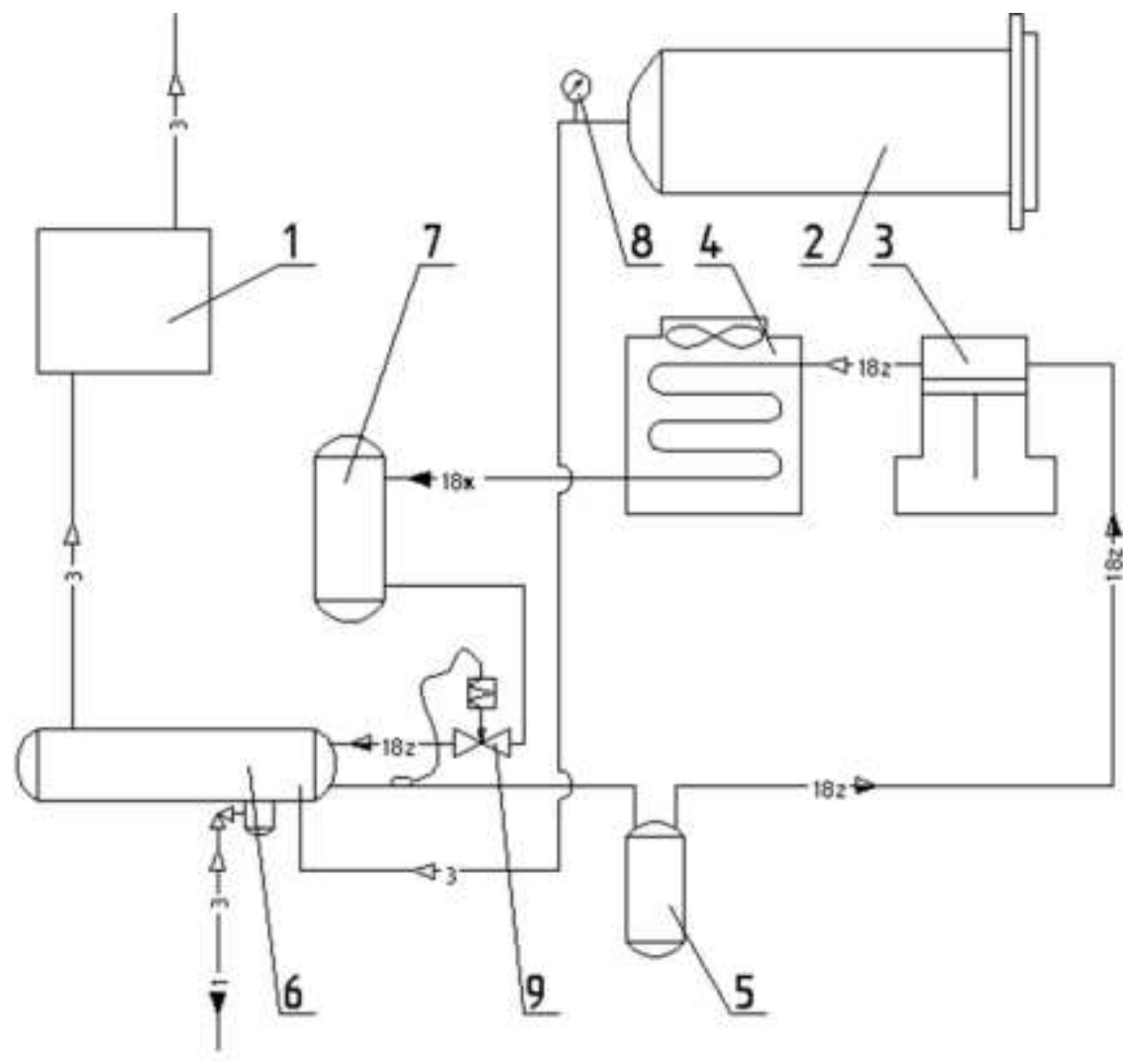

Fig. 1. Scheme of an experimental vacuum drying unit: 1- vacuum pump; 2 - a drying chamber; 3 - compressor; 4 - capacitor; 5 - liquid separator; 6 desublimator; 7 - receiver; 8 - a vacuum gauge; 9 - thermostatic valve

\section{RESULTS AND DISCUSSIONS}

Initially, vacuum drying process was carried out at different heat flux densities. This parameter was varied in the range from 2 to $10 \mathrm{~kW} / \mathrm{m}^{2}$ in increments of $2 \mathrm{~kW} / \mathrm{m}^{2}$. The thickness of the drying layer was $10 \mathrm{~mm}$.

Figure 2 shows graphs of changes in the relative mass of honey during the vacuum drying process at different heat flux densities, and Figure 3 presents the rate of relative mass changes.

The entire vacuum drying process can be conveniently divided into three periods - a) period of the vacuum drying unit entering the needed mode, when there is a gradual increase in the rate of moisture removal, b) period of constant drying rate, at which most of the moisture is removed and c) period of the falling drying rate. With an increase in heat flux density, the drying time decreases: with a heat flux density of 2,4 and $6 \mathrm{~kW} / \mathrm{m}^{2}$, the drying time was $270 \pm 10$, $240 \pm 10$ and $225 \pm 10 \mathrm{~min}$, and with a heat flux of 8 and $10 \mathrm{~kW} / \mathrm{m}^{2}$ the drying time was $210 \pm 10$ and $195 \pm 10 \mathrm{~min}$, respectively. At the same time, the moisture content of the dehydrated product changes as well: with an increase in the heat flux density from 2 to $10 \mathrm{~kW} / \mathrm{m}^{2}$, it rises from 4.5 to $5 \%$. 


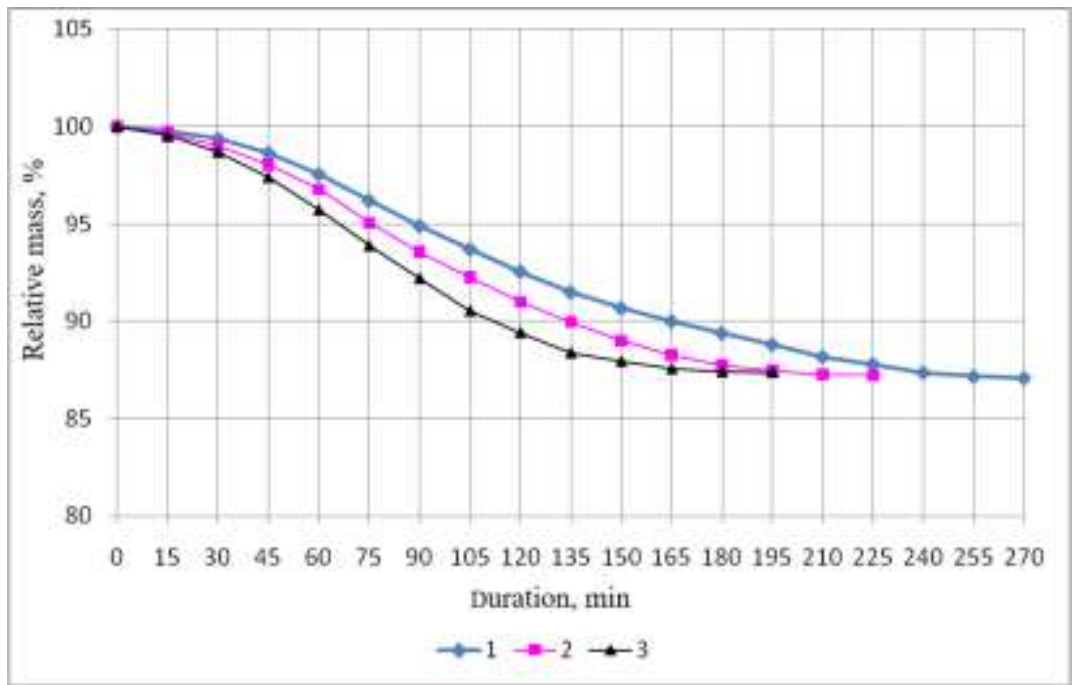

Fig. 2. Graphs of honey relative mass changes during the vacuum drying process at a heat flux density of: $1-2 \mathrm{~kW} / \mathrm{m}^{2} ; 2-6 \mathrm{~kW} / \mathrm{m}^{2} ; 3-10 \mathrm{~kW} / \mathrm{m}^{2}$

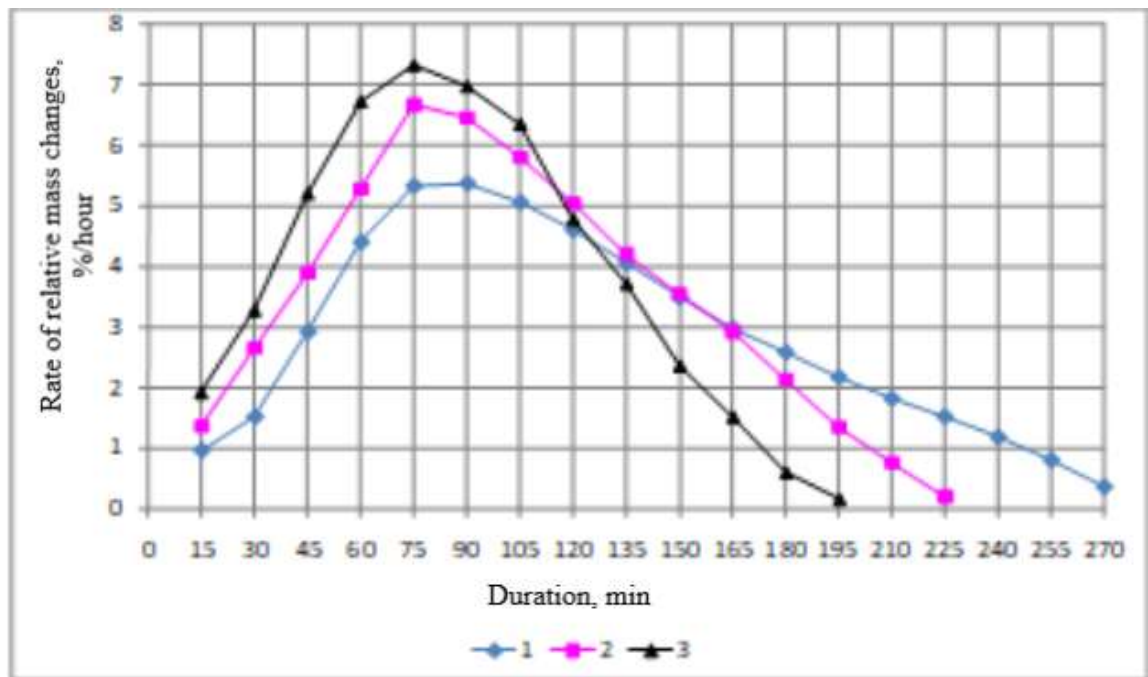

Fig. 3. Rate of relative mass changes during the vacuum honey drying process at a heat flux density of: $1-2 \mathrm{~kW} / \mathrm{m}^{2} ; 2-6 \mathrm{~kW} / \mathrm{m}^{2} ; 3-10 \mathrm{~kW} / \mathrm{m}^{2}$

Further, an organoleptic evaluation of dehydrated honey was carried out. The assessment included such indicators as taste, texture, smell and color; they were evaluated on a 10point scale. Table 2 shows the results of this assessment.

TABLE II. RESULTS OF THE ORGANOLEPTIC EVALUATION OF DRY HONEY, POINTS

\begin{tabular}{|l|l|l|l|l|l|}
\hline \multirow{2}{*}{ Indicator } & \multicolumn{6}{|c|}{ Heat flux density, $\mathbf{~ k W} / \mathbf{m}^{2}$} \\
\cline { 2 - 7 } & $\mathbf{2}$ & $\mathbf{4}$ & $\mathbf{6}$ & $\mathbf{8}$ & $\mathbf{1 0}$ \\
\hline Taste & 8 & 8 & 7 & 7 & 7 \\
\hline Color & 9 & 9 & 8 & 8 & 8 \\
\hline Odor & 9 & 9 & 9 & 8 & 7 \\
\hline Consistency & 10 & 9 & 9 & 8 & 6 \\
\hline Total score & 36 & 35 & 33 & 31 & 28 \\
\hline
\end{tabular}

The lower the heat flux density is, the more uniform the distribution of the temperature field in the product is ensured at the initial stage of drying, which is especially beneficial for such an indicator as consistency. At high values of the heat flux density, the consistency of the dehydrated product became heterogeneous; this fact was reflected in the quality indicators. Based on the above data, it is possible to conclude the feasibility of vacuum honey drying at a heat flux density of $4 \mathrm{~kW} / \mathrm{m}^{2}$, as this mode provides a relatively high organoleptic evaluation, the correct consistency of the final product and a short duration of dehydration (240 min).

At the following stage of the research, experiments were carried out on vacuum honey drying at different layer thickness: $5,10,15$, and $20 \mathrm{~mm}$. The other drying parameters remained unchanged, the heat flux density was $4 \mathrm{~kW} / \mathrm{m}^{2}$. Table 3 shows the indicators of vacuum drying of honey when selecting the layer thickness.

TABLE III. INDICATORS OF VACUUM HONEY DRYING WHEN SELECTING A LAYER THICKNESS

\begin{tabular}{|l|l|l|l|l|}
\hline \multirow{2}{*}{ Indicator } & \multicolumn{4}{|c|}{ Layer thickness, mm } \\
\cline { 2 - 5 } & $\mathbf{5}$ & $\mathbf{1 0}$ & $\mathbf{1 5}$ & $\mathbf{2 0}$ \\
\hline Duration of drying, min. & 180 & 240 & 275 & 300 \\
\hline Moisture content, \% & 4,3 & 4,6 & 4,9 & 5,4 \\
\hline Organoleptic evaluation, points & 37 & 35 & 34 & 31 \\
\hline
\end{tabular}


It was found that the increase in the layer thickness entails an increase in the drying time, an increase in the moisture content of the dehydrated product and a decrease in its quality. However, this increases the productivity of the drying unit, which is especially important for the organization of industrial production of dried honey. It is advisable to dry with a layer thickness of $15 \mathrm{~mm}$. The moisture content of the product does not exceed $5 \%$, the organoleptic rating is 34 points out of 40 , and the duration of dehydration is $275 \pm 10$ minutes.

\section{CONCLUSION}

Thus, on the basis of the conducted studies, the following effective modes of vacuum honey drying were determined: the heat flux density $-4 \mathrm{~kW} / \mathrm{m}^{2}$, the product layer thickness $15 \mathrm{~mm}$. It is advisable to dehydrate honey at a residual pressure of $4 \pm 0.5 \mathrm{kPa}$ and a temperature in the vacuum chamber of $40^{\circ} \mathrm{C}$. Under these conditions, the drying time is $275 \pm 10$ minutes, and the organoleptic evaluation of the dry product is 34 points out of 40 .

\section{References}

[1] V.A. Ermolaev, "Kinetics of the vacuum drying of cheeses", Foods and Raw Mater., vol. 2, no. 2, pp. 130-139, 2014.

[2] V.A. Ermolaev, "Effect of vacuum drying on microstructure of semisolid cheese", Foods and Raw Mater., vol. 2, no. 1, pp. 11-16, 2014.

[3] J. Lope, A. Vega-Galvez, C. Bilbao-Sainz, Bor-Sen Chiou, E. Uribe, I. Quispe-Fuentes, "Influence of vacuum drying temperature on: Physico-chemical composition and antioxidant properties of murta berries", J. of Food Process Engineer., vol. 40, no. 6, UNSP e12569, 2017.

[4] L. Xie, Arun S. Mujumdar, F. Xiao-Ming et al., "Far-infrared radiation heating assisted pulsed vacuum drying (FIR-PVD) of wolfberry (Lycium barbarum L.): Effects on drying kinetics and quality attributes", Food and Bioprod. Proc., vol. 102, pp. 320-331, 2017

[5] M. Rabeta, S. Lin, "Effects of different drying methods on the antioxidant activities of leaves and berries of Cayratia trifolia, Sains Malaysiana, vol. 44, no. 2, pp. 275-280, 2015.

[6] M. Zdravko, N. Aleksandra, D. Stela, V. Radomir, "Optimization of frozen wild blueberry vacuum drying process", Hemijska industry, vol. 69, no. 1, pp. 77-84, 2015

[7] Mu Yanqiu, Zhao Xinhuai, Liu Bingxin, Liu Chenghai, Zheng Xianzhe, "Influences of microwave vacuum puffing conditions on anthocyanin content of raspberry snack", Int. J. of Agricult. and Biolog. Engineer., vol. 6 , no. 3, pp. 80-87, 2013

[8] A. Horszwald, H. Julien, W. Andlauer, "Characterisation of Aronia powders obtained by different drying processes", Food chem., vol. 141, no. 3, pp. 2858-2863, 2013.

[9] Yuan-hui Li, Ya-ru Qi, Zhen-feng Wu, Ya-qi Wang, Xue-cheng Wang, Fang Wang, Ming Yang, "Comparative study of microwave-vacuum and vacuum drying on the drying characteristics, dissolution, physicochemical properties, and antioxidant capacity of Scutellaria extract powder", Powder technol., 317, pp. 430-437, 2017.

[10] S. Nile, S. Park, "Edible berries: bioactive components and their effect on human health", Nutrition, vol. 30, no. 2, pp. 134-144, 2014.

[11] J. Kellogg, J. Wang, C. Flint, M. Lila, D. Ribnicky et al., "Alaskan wild berry resources and human health under the cloud of climate change", J. of Agricult. and Food Chem., vol. 58, no. 7, pp. 3884-3900, 2010.
[12] C. Bowen-Forbes, M. Nair, Y. Zhang, "Anthocyanin content, antioxidant, anti-inflammatory and anticancer properties of blackberry and raspberry fruits", J. of Food Composit. and Anal., vol. 23, no. 6, pp. 554-560, 2010.

[13] S. Afrin, M. Gasparrini, T. Forbes-Hernandez, P. Reboredo-Rodriguez et al., "Promising health benefits of the strawberry: a focus on clinical studies", J. Agricult. Food Chem., vol. 64, no. 22, pp. 4435-4449, 2016.

[14] A. Artnaseaw, S. Theerakulpisut, C. Benjapiyaporn, "Development of a vacuum heat pump dryer for drying chilli”, Biosyst. Engineer., vol. 105, no. 1 , pp. 130-138, 2010.

[15] B. Zecchi, L. Clavijo, J. Martínez Garreiro, P. Gerla, "Modeling and minimizing process time of combined convective and vacuum drying of mushrooms and parsley", J. of Food Engineer., vol. 104, no. 1, pp. 49-55, 2011

[16] U. Mannanov, Sh. Mamatov, B. Shamsutdinov, "Research and study mode vacuum infrared drying vegetables", Austrian J. of Techn. and Natural Sci., vol. 3-4, pp. 38-41, 2016.

[17] V.A. Ermolaev, "Research of vacuum drying peculiarities of wild berries", Biointerface Res. in Appl. Chem., vol. 8, iss. 4, pp. 3483-3489, 2018.

[18] V.A. Ermolaev, "Development of mathematical model for vacuum cheese drying", Biointerface Res. in Appl. Chem., vol. 9, iss. 1, pp. 3830-3833, 2019.

[19] X. Li, X. Xie, C.H. Zhang, S. Zhen, W. Jia, "Role of mid- and farinfrared for improving dehydration efficiency in beef jerky drying", Drying Technol., vol. 36, no. 3, pp. 283-293, 2018.

[20] H. Jarahizadeh, S. Taghian Dinani, "Influence of applied time and power of ultrasonic pretreatment on convective drying of potato slices", Food Sci. and Biotechnol., vol. 5, no. 3, pp. 270-275, 2018.

[21] F. Vallespir, O. Rodriguez, V.S. Eim, C. Rossello, S. Simal, "Freezing pre-treatments on the intensification of the drying process of vegetables with different structures", J. of Food Engineer., vol. 239, pp. 83-91, 2018.

[22] Y. Bai, Z. Luan, "The effect of high-pulsed electric field pretreatment on vacuum freeze drying of sea cucumber", Int. J. of Appl. Electromagnetics and Mechan., vol. 57, no. 2, pp. 247-256, 2018.

[23] M.F. Balzarini, M.A. Reinheimer, N.J. Scenna, M.C. Ciappini, "Comparative study of hot air and vacuum drying on the drying kinetics and physicochemical properties of chicory roots", J. of Food Sci. and Technol., vol. 55, no. 10, pp. 4067-4078, 2018.

[24] M.R. Alam, J.G. Lyng, D. Frontuto, F. Marra, L. Cinquanta, "Effect of pulsed electric field pretreatment on drying kinetics, color, and texture of parsnip and carrot”, J. of Food Sci., vol. 83, no. 8, pp. 2159-2166, 2018.

[25] O. Alves-Filho, "Energy effective and green drying technologies with industrial applications", Chem. Engineer. Transact., vol. 70, pp. 145-150, 2018.

[26] V.S.O. Farias, L.F. Araujo, W.P. Silva, C.M.R. Franco et al., "Drying study of ceramic tiles using three-dimensional analytical solution of the diffusion equation", JP J. of Heat and Mass Transfer, vol. 15, no. 2, pp. 409-432, 2018.

[27] B. Sritongtae, K. Duangmal, M.R.A. Morgan, "Drying kinetics, physicochemical properties, antioxidant activity and phenolic composition of foam-mat dried germinated rice (vigna umbellata) hydrolysate", Int. J. of Food Sci. and Technol., vol. 52, no. 7, pp. 1710-1721, 2017.

[28] J. Li, J.-Q. Wan, Y.-G. Zhong et al., "Effect of controlled freezing-point vacuum drying on color and flavor of muraenesox cinereus fillets", J. of Food Process Engineer., vol. 40, no. 1, pp., 122-125, 2017.

[29] G. Konuspaeva, N. Aleilawi, M. Al-Shumeimyri et al., "Manufacture of dry- and brine-salted soft camel cheeses for the camel dairy industry", Int. J. of Dayry Technol., vol. 70, no. 1, pp. 92-101, 2017. 